\title{
Characterization and evaluation of potential impacts in the environment of residual fiber from cellulose
}

\author{
Alvaro João Zonta Neto' \\ Mariana Gomes Oliveira" \\ Everton Skoronski"I \\ Maurício Vicente Alves ${ }^{\mathrm{IV}}$
}

\begin{abstract}
The search for final alternative destinations for residue from industrial processes is a growing problem. Pulp and paper industries generate large amounts of residue, which are not always reused or do not receive adequate destination. An alternative is its reuse, using the final disposal of the residue in the soil, for its potential to inactivate part of the chemical compounds, allowing its use as agricultural inputs of low cost. The purpose of this study was to analyze the final residue of the wastewater treatment plant of a pulp and paper industry. Industries in this economic sector produce high resistance and low lignin cellulose pulp and recovers the chemicals used, reducing costs. In order to pre-evaluate this disposal possibility, this study carried out the classification of the waste classifying the hazardousness of the cellulose fiber, and its behavior under solubilization and leaching tests. The results of the analysis showed the potential of solubilization of substances in water above the maximum permissible value (MPV), characterizing the residue as non-inert and non-hazardous Class IIA. This fact implies that safety doses must be evaluated before its application in soil. Further studies must be carried out in terms of toxicological effects and its potential to be applied to crops.
\end{abstract}

Keywords: Residue; Impacts; Paper and cellulose

\section{Resumo}

A busca por destinações finais alternativas para os resíduos de processos industriais é uma problemática crescente. As indústrias de papel e celulose geram grandes quantidades de resíduos, que nem sempre são reutilizados ou não recebem a destinação adequada. Uma alternativa é seu reaproveitamento, utilizando a disposição final do resíduo no solo, pelo potencial do mesmo em inativar parte dos compostos químicos, possibilitando seu uso como insumos agrícolas de baixo custo. Este estudo teve por finalidade analisar o resíduo final da estação de tratamento de efluentes de uma indústria de papel e celulose. Indústrias deste setor produzem uma polpa de celulose de alta resistência e com baixo teor de lignina, além de recuperar os químicos utilizados, diminuindo custos. De forma a pré-avaliar esta possibilidade de disposição, este estudo realizou a classificação do resíduo classificando a periculosidade da fibra de celulose, e seu comportamento sob ensaios de solubilização e lixiviação. As análises conduzidas demonstraram características de solubilização de substâncias em

' Graduating, Environmental and Sanitary Engineering, University of the State of Santa Catarina (UDESC), Lages,

SC, Brazil. alvarozonta@gmail.com

" Graduating, Environmental and Sanitary Engineering, University of the State of Santa Catarina (UDESC), Lages, SC, Brazil.marianagomes.udesc@gmail.com

II' Doctor, Environmental and Sanitary Engineering, University of the State of Santa Catarina (UDESC), Lages, SC, Brazil.skoronski@cav.udesc.br

IV Doctor, Agronomy, University of the West of Santa Catarina (UNOESC), Xanxerê, SC, Brazil. 
água acima dos níveis de valor máximo permitido (VMP), caracterizando o resíduo como não inerte e não perigoso Classe IIA. Isso significa que doses seguras devem ser estudadas antes de sua aplicação no solo. Estudos adicionais devem avaliar os efeitos toxicológicos e o seu potencial na agricultura.

Palavras-chave: Resíduo; Impactos; Papel e celulose 


\section{Introduction}

The search for new final destinations for residue from industrial processes has grown due to the interest of the industries in searching for more viable alternatives in the economic and environmental scope. Nowadays, it is known that the industries responsible for the manufacture and transformation of materials produce, to a greater or lesser degree, a certain amount of residue that is not always reused or has an ecologically correct destination.

In the forestry sector, the generation of residue has a significant impact, mainly for the pulp and paper industries, which face environmental problems due to the significant generation of residue from its production. According to Bellote et al. (1998), the generation of 48 tons of residue for every 100 tons of pulp produced makes it impossible to choose landfills as final destination, due to the high maintenance and implantation costs, as well as the need for handling with care recurring risks of environmental contamination.

As an alternative to the landfill, the use of industrial residue in agriculture has proved to be viable considering the soil's potential to inactivate part of the chemical compounds present in such residue, reducing its pollutant potential and, at the same time, the residue can be used as low-cost agricultural inputs.

Residue from pulp and paper industries has been highlighted when it comes to application to the soil and its consequences for the various types of plantations. As evidenced by the studies carried out in the area, the potential of the pulp and paper production residues is due to the capacity to raise soil $\mathrm{pH}$ and to positively influence nutrient cycling, functioning as a nutrient supply demanded by the crops (ALMEIDA et al. , 2008).

It is worth mentioning that the characteristics of a residue generated by an industry depend directly on its production process. In the pulp and paper sector, in general, the industrial interest is the extraction of wood pulp, separating it from lignin, minerals and resins, producing a pulp with high quality, with competitive prices and with minimum environmental impact. There are different industrial methods that 
realize the obtaining of cellulosic fibers, however it is highlighted as main method the pulp kraft, which allows the obtaining of a pulp of high resistance and with low lignin content, besides being distinguished for having as principal the recovery of the chemicals used (FAVARO, 2015).

The pulping process using the kraft method uses what is called a white liquor, formed of sodium hydroxide $(\mathrm{NaOH})$ and sodium sulfide $\left(\mathrm{Na}_{2} \mathrm{~S}\right)$, for the digestion of wood lignin and the formation of cellulose pulp. At the end of this stage, the black liquor is expelled from the digester and has its composition based on: chemicals used, dissolved lignin and carbohydrates. While pulp goes into the industrial process, it is necessary that black liquor be recovered, due to economic and environmental issues. Briefly, black liquor is withdrawn from the pulp in brown pulp washing systems and then evaporated, so that it is concentrated, and its product is burned in the recovery boilers. The solid residue of this stage is called dregs (FOELKEL, 2011).

The process characteristic with reuse begins already in the boiler, where the steam produced is used in pulping and papermaking, as well as for the production of electric energy for the factory. After molten, the black liquor goes into a melt dissolution tank, forming the green liquor which has as components sodium carbonate $\left(\mathrm{Na}_{2} \mathrm{CO}_{3}\right)$ and sodium sulfide $\left(\mathrm{Na}_{2} \mathrm{~S}\right)$. Following the process occurs the causticisation step, in which the sodium carbonate is placed in reaction with lime $(\mathrm{CaO})$ and gives rise to lime mud $\left(\mathrm{CaCO}_{3}\right)$ and sodium hydroxide, which can be reincorporated into the industrial process together with the sodium sulfide to form the white liquor again (GOMIDE et al, 2006). The residue from the preparation of hydrated lime, consisting mainly of lime mud is called grits. The flow chart of the kraft recovery cycle can be seen in Figure 1.

Throughout the process, part of the residues mentioned above and fluids from the production process generate effluents that are conveyed to the effluent treatment plant. As is common in effluent treatment processes, after the removal of the liquid portion of the treated effluent, a semi-solid and pasty residue called effluent sludge is generated. In pulp and paper industries, in addition to the residues mentioned above, 
this sludge is also composed of a large concentration of cellulose which makes it commonly called cellulose fiber, because of its physical and chemical characteristics.

Figure 1 - Kraft recovery cycle flowchart (GOMIDE et al, 2006)

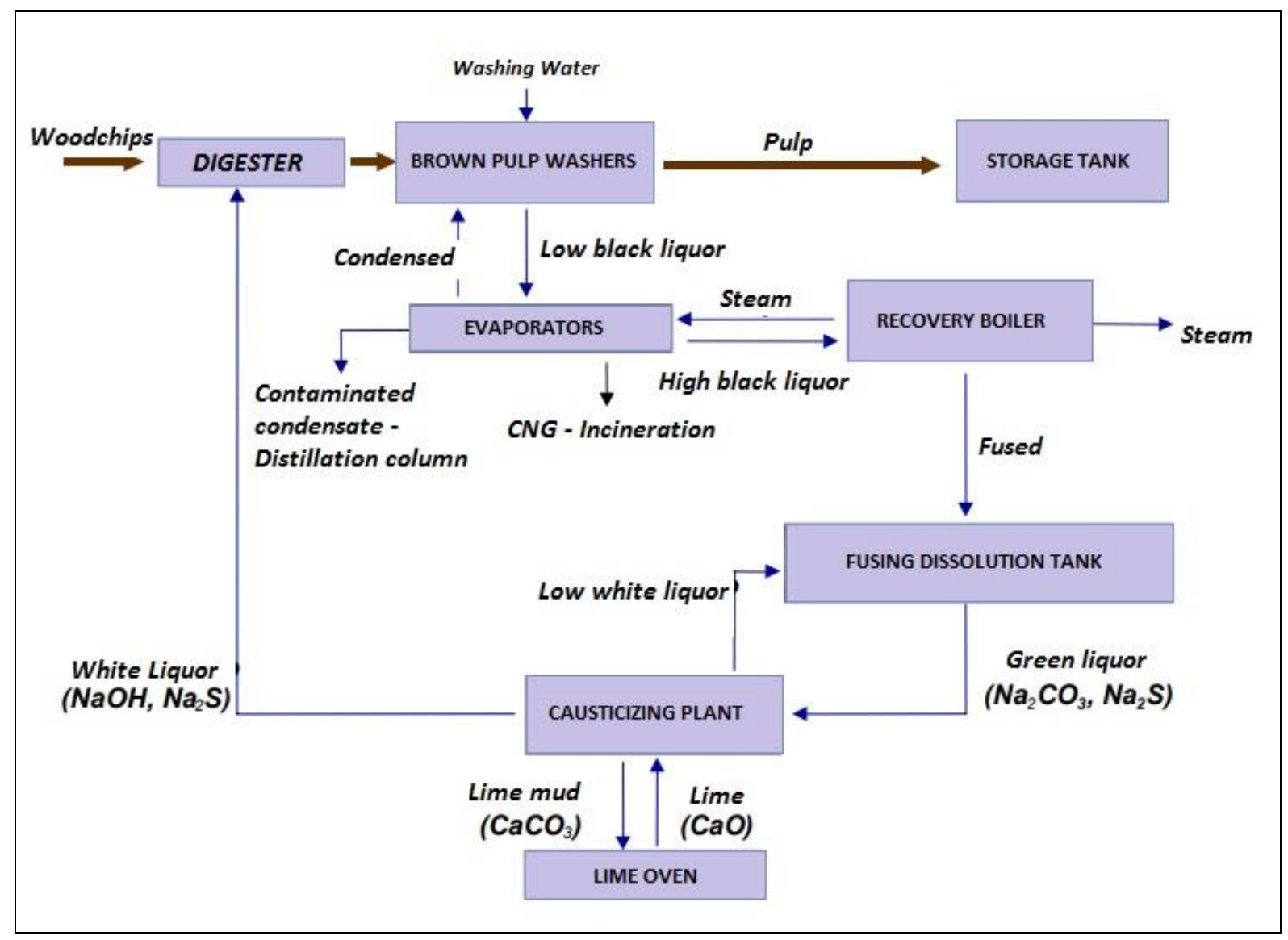

Kraft pulp represents a large part of the Brazilian pulp and paper sector, with South America being considered as the largest producer of eucalypt kraft pulp in the world. This continent is becoming the world's pole of production of eucalyptus pulp, so it is imperative that South America lead research, innovation and development initiatives, not only in the production and use of cellulosic pulp, but also in studies to the reuse or treatment of solid wastes from their production, such as the aforementioned disposal in the soil.

However, the disposal of residue of any kind in the soil should not be carried out without first conducting studies in order to take due account of possible changes in the physical and chemical properties of the soil. Knowing the behavior of the material 
in the soil and its implications is essential since the interactions with the medium result in smaller or larger scale impacts to the biotic and abiotic environment.

Thus, with the objective of analyzing the previous viability for the application of the cellulose fiber residue in the soil, this study has as premise to carry out the classification of this residue according to the norms and current legislation in order to classify the hazardousness of the fiber of cellulose, determining whether there are characteristics that make it a hazardous or non-hazardous, inert or non-inert residue, as well as its behavior under solubilization and leaching tests.

\section{Material and methods}

The by-product assessed in this study consists of residual fiber from cellulose manufacture. This recovered fiber are residues from the industrial equipment, carried to the industrial wastewater treatment plant. Since this residue is composed of a high concentration of organic matter, it attracts attention to its use in the agriculture

The characterization of the residue of the cellulose fiber, as the current legislation indicates, is an essential stage to ensure the correct disposal and reuse of this residue. The chemical analysis and classification were performed according to the recommended methodology indicated by the Brazilian Association of Norms and Techniques (ABNT).

Therefore, to carry out the sampling, the ABNT NBR 10007/2004 standard (ABNT, 2004a) was used, which determines the standards for the sampling procedure of a representative amount of solid residue, aiming to determine its characteristics regarding classification, treatment methods, among others.

For the residue classification test, ABNT NBR 10004/2004 (ABNT, 2004b) was used - Residue classification as to its potential risks to the environment and public health, so that they can be properly managed. This test analyses if the sample exhibits flammable, corrosive, pathogenic and toxic characteristics.

The leaching test was carried out using the ABNT NBR 10005/2004 standard (ABNT, 2004c) - Procedure for obtaining a leach extract from solid residue that 
establishes the requisites required to obtain this extract, in order to differentiate the residue classified by ABNT NBR 10004 /2004 as class I - hazardous - and class II - non hazardous. The leaching test was performed following the ABNT standards, in which a $100 \mathrm{~g}$ mass of the sample was put in contact with $2000 \mathrm{~mL}$ of extraction solution 1 (5.7 $\mathrm{mL}$ of glacial acetic acid, distilled and deionized water and $64.3 \mathrm{~mL}$ of $1.0 \mathrm{~N} \mathrm{NaOH}$, made up to $1 \mathrm{~L}$ volume) for $18 \pm 2$ hours at $23 \pm 2^{\circ} \mathrm{C}$.

In the solubilization test, the reference standard was ABNT NBR 10006/2004 (ABNT, 2004d) - Procedure to obtain a solubilized solid residue extract, in order to differentiate the residues classified in ABNT NBR 10.004 / 2004 as class II A - not inert and class II B - inert. The solubilization test was carried out according to the ABNT procedures, in which a $250 \mathrm{~g}$ mass of the sample was put in contact with $1000 \mathrm{~mL}$ of deionized water for 7 days at a $23 \pm 2{ }^{\circ} \mathrm{C}$ temperature.

\section{Results and discussion}

The cellulose fiber characterization following the ABNT NBR 10004/2004 standard showed that the residue did not present flammability, reactivity, corrosivity, toxicity and pathogenicity characteristics according to the terms considered by the standard. Therefore, the sample was classified as non-hazardous (Class II). In terms of reactivity, the presence of sulfide must be evaluated and the residue must present lower than $500 \mathrm{mg}$ of releasable $\mathrm{H}_{2} \mathrm{~S}$ according to the United States Environmental Protection Agency (USEPA) - SW 846 test methods, for the solid waste evaluation test (USEPA, 2015). In our study we did not identified the presence of sulfide.

It is important to mention that the evaluation of sulfide in cellulosic fiber is of importance. Its occasional presence in an residue is associated to the use of sulfur products in the composition of the digestion liquor, causing secondary reactions with some organic components that are present in the raw material, giving rise to the organosulfides, gaseous materials that have an unpleasant odor. Besides the hydrogen sulfide $\left(\mathrm{H}_{2} \mathrm{~S}\right)$, other compounds are also considered organosulfurized such as: methyl mercaptan $\left(\mathrm{CH}_{3} \mathrm{SH}\right)$, dimethyl sulfide $\left[\left(\mathrm{CH}_{3}\right)_{2} \mathrm{~S}\right]$ and dimethyl disulfide 
[( $\left.\left(\mathrm{CH}_{3}\right)_{2} \mathrm{~S}_{2}\right]$. These compounds make up a set called TRS (Total Reduced Sulfur) or reduced sulfur compounds (MISHAL, 1975). These compounds are considered to be severe air pollutants even at parts per billion ( $p p b)$ levels (OSSES, 1991). So, this pollutant must be considered in studies involving waste reuse.

The determination of the transferability of organic and inorganic substances present in the residues was carried out using the leaching test determined by the ABNT NBR 10005/2004 standard, resulting in a leached solution with pH of 5.47 after the contact period. For the results of the leaching test, it can be inferred that none of the analyzed parameters are above the maximum permitted value (MPV), conferring non-toxicity characteristics, in the referred terms of the standard.

The solubilization test in the terms of the ABNT NBR 10006/2004 standard, has the objective of identifying the concentration of water-soluble substances. The results obtained for the solubilization test are set out in the Table 1.

Table 1 - Determination values of the solubilization test

\begin{tabular}{lccc}
\hline $\begin{array}{c}\text { Solubilization } \\
\text { Parameters }\end{array}$ & Obtained value & Unit & MPV \\
\hline Aldrin + Dieldrin & $<0.0003$ & $\mathrm{mg} / \mathrm{L}$ & 0.00003 \\
Aluminum & 0.412 & $\mathrm{mg} / \mathrm{L}$ & 0.2 \\
Arsenic & $<0.002$ & $\mathrm{mg} / \mathrm{L}$ & 0.01 \\
Barium & 0.72 & $\mathrm{mg} / \mathrm{L}$ & 0.7 \\
Cadmium & 0.022 & $\mathrm{mg} / \mathrm{L}$ & 0.005 \\
Lead & $<0.002$ & $\mathrm{mg} / \mathrm{L}$ & 0.01 \\
Cyanide & $<0.005$ & $\mathrm{mg} / \mathrm{L}$ & 0.07 \\
Chlordane & $<0.0002$ & $\mathrm{mg} / \mathrm{L}$ & 0.0002 \\
Chloride & 7.023 & $\mathrm{mg} / \mathrm{L}$ & 250 \\
Copper & $<0.006$ & $\mathrm{mg} / \mathrm{L}$ & 2 \\
Chrome & $<0.005$ & $\mathrm{mg} / \mathrm{L}$ & 0.05 \\
2.4-D & $<0.03$ & $\mathrm{mg} / \mathrm{L}$ & 0.03
\end{tabular}




\begin{tabular}{|c|c|c|c|}
\hline $\mathrm{DDT}+\mathrm{DDD}+\mathrm{DDE}$ & $<0.002$ & $\mathrm{mg} / \mathrm{L}$ & 0.002 \\
\hline Endrin & $<0.0004$ & $\mathrm{mg} / \mathrm{L}$ & 0.0004 \\
\hline Phenols & 0.74 & $\mathrm{mg} / \mathrm{L}$ & 0.01 \\
\hline Iron & 96.36 & $\mathrm{mg} / \mathrm{L}$ & 0.3 \\
\hline Fluoride & $<0.05$ & $\mathrm{mg} / \mathrm{L}$ & 1.5 \\
\hline $\begin{array}{l}\text { Heptachlor } \\
\text { Expoxide }\end{array}$ & $<000003$ & $\mathrm{mg} / \mathrm{L}$ & 0.00003 \\
\hline Hexachlorobenzene & $<0.001$ & $\mathrm{mg} / \mathrm{L}$ & 0.001 \\
\hline Lindane & $<0.002$ & $\mathrm{mg} / \mathrm{L}$ & 0.002 \\
\hline Manganese & 21.88 & $\mathrm{mg} / \mathrm{L}$ & 0.1 \\
\hline Mercury & $<0.0002$ & $\mathrm{mg} / \mathrm{L}$ & 0.001 \\
\hline Methoxychlor & $<0.02$ & $\mathrm{mg} / \mathrm{L}$ & 0.02 \\
\hline Nitrate & 0.335 & $\mathrm{mg} / \mathrm{L}$ & 10 \\
\hline Silver & $<0.002$ & $\mathrm{mg} / \mathrm{L}$ & 0.05 \\
\hline Selenium & $<0.002$ & $\mathrm{mg} / \mathrm{L}$ & 0.01 \\
\hline Sodium & 209.59 & $\mathrm{mg} / \mathrm{L}$ & 200 \\
\hline Sulfate & 149.775 & $\mathrm{mg} / \mathrm{L}$ & 250 \\
\hline Surfactants & $<0.10$ & $\mathrm{mg} / \mathrm{L}$ & 0.5 \\
\hline Toxaphene & $<0.005$ & $\mathrm{mg} / \mathrm{L}$ & 0.005 \\
\hline 2.4.5- $\mathrm{T}$ & $<0.002$ & $\mathrm{mg} / \mathrm{L}$ & 0.002 \\
\hline 2.4.5-TP & $<0.03$ & $\mathrm{mg} / \mathrm{L}$ & 0.03 \\
\hline Zinc & 0.192 & $\mathrm{mg} / \mathrm{L}$ & 5 \\
\hline pH - Solubilized & 6.45 & - & - \\
\hline
\end{tabular}

*The lines highlighted in bold show the parameters analyzed that extrapolated the maximum value by the ABNT NBR 10006/2004 standard

From the results obtained for the solubilization test, the values found above the maximum permitted value for the manganese, aluminum, barium, cadmium, phenols, iron, and sodium are highlighted. This shows that the cellulose residue used in the study does not present inert characteristics, that is, it demonstrates characteristics of solubilization in water for some of its components, that way presenting a potential of 
degradation or contamination of the water or the atmosphere. Therefore, the waste is classified as class IIA (non-inert and non-hazardous)

The cadmium (Cd) concentration above the allowed value may be related to the industrial machinery since this element is applied for the steel and iron covering due to its high resistance to corrosion. It is known that in the kraft process, the cadmium is found in low concentrations in the raw materials and are removed by the liquor filtration system and by the removal of dregs and grits (FOEKEL, 2011). The bioaccumulation potential of cadmium in aquatic plants, invertebrates, fish, and mammals makes this an element to be closely monitored, requiring attention to its final disposal.

The presence of phenols is often associated by the pulping and papermaking process in the industry, due to the black liquor, an effluent with high organic load generated in the kraft pulp process, which is responsible for the removal of approximately $90 \%$ of the lignin present in the wood (PERALTA-ZAMORA et al, 1997). The phenols determination before any disposal of the residue is essential since this compound might be considered toxic and potentially carcinogenic (SANTANA et al, 2009) and may affect the taste and odor of drinking water even in low concentrations. At high concentrations, phenolic compounds have destructive potential on aquatic fauna and flora, due to its toxic characteristics and the high demand for oxygen.

For the pulp and paper industry, the presence of manganese $(\mathrm{Mn})$ is seen as a factor to be avoided in the production process since, when mixed with iron (Fe) and copper $(\mathrm{Cu})$, it causes negative action on hydrogen peroxide stability, the substance used in acid washing for cellulose bleaching. Manganese and iron can cause the catalytic decomposition of hydrogen peroxide, generating hydroxyl radicals that attack and damage the cellulose structure, reducing its physical properties (SIQUEIRA, SILVA FILHO \& SECCOMBRE, 2012).

The industries adopt chemical processes to reduce the iron and manganese contents, so it is believed that the high values recorded for these two parameters are related to their removal in the production process, to their presence in the wood, water or even to their generation by the equipment of the factory, causing them to be 
carried to the treatment plant and consequent residue. For soil application, its known that manganese is a nutrient and a limiting factor in the interaction with plants. One of the main problems for soybean cultivation, for example, is Mn-deficient soils (ROSOLEM et al., 1992). However, establishing critical levels of manganese in the soil becomes difficult, since its soil determination is strongly influenced by $\mathrm{pH}$, and it is necessary to accomplish more specific studies for the application of various manganese dosages on different $\mathrm{pH}$ values.

For the aluminum levels (Al) observed, it is known that the major inputs of this element in the kraft process industries occur by the industrial water, by treatment using aluminum sulfate as a flocculant, and by the limestone or lime used for the calcium replacement in the lime system. Although most of it is precipitated by the recovery system and collected by the green liquor filtration system (FOEKEL, 2011), some of the aluminum may not be recovered and can be carried to the final residue of the industrial process.

The special attention given to aluminum is due to the fact that it is a neurotoxic compound with potential to cause damage to human health when found in high concentrations. In the soil application, studies report that although Al is not considered an essential element for plant species, the application in low concentrations can stimulate the growth of some plants, but on the other hand, if not applied in the correct concentrations for each species, can cause cytological abnormalities in plants, retarding the root growth (FERREIRA, MOREIRA \& RASSINI, 2006).

The observed presence of sodium $(\mathrm{Na})$ in the solubilized has its main origin due to the use of compounds of this element in the industrial process of lignin digestion and bleaching of the cellulosic pulp. Although the kraft process presents low losses of sodium and sulfate due to the mechanisms of recovery, it is estimated that the losses of these elements are between 5 and 10\%, which may justify the presence in the final residue (FOELKEL, 2011).

A possible increase in the sodium concentration in the soil due to the disposal of the residue shall be observed with caution and demonstrates the necessity of 
monitoring, since with the increase of the exchangeable $\mathrm{Na}^{+}$content in the soil, some important properties of the soil can be impaired from the agronomic point of view, such as clay and organic substances dispersion (ALMEIDA et al, 2007). Another study carried out with the disposal of residues with high sodium content in sandy soils showed a higher susceptibility of the residues to the leaching of sodium in the soil profile and could contaminate the groundwater (TRIGUEIRO, 2006).

The occurrence of barium (Ba) in pulp and paper industries comes almost exclusively from wood and tree bark. Barium is an element that demands special attention for the industries since its precipitation as barium sulphate is one of the most undesirable in the fiber line. This is due to the low solubility of the barium precipitate, making it difficult to be removed mechanically or chemically, being a potential factor of incrustations in the machinery of the industry (FOELKEL, 2011). Thus, the precipitate is removed with the combination of mechanical treatments with strong water jets, chelating agents, and acid washing, which can then carry concentrations of this element up to the final residue of the production.

Although it is found naturally in the soil, the high levels of barium can be toxic to plants and invertebrates, also interfering with the sulfur availability, due to the formation of low solubility sulfates (KUPERMAN et al, 2006). As for human health, it is known that only $2 \%$ of ingested barium is absorbed by the body, tending to accumulate in the bones, replacing calcium.

\section{Final Considerations}

The results obtained by the tests infer that the residual fiber of pulp and paper industry presented values that do not confer inert characteristics and classifies it as non-hazardous Residue Class IIA. It is worth mentioning that the present study had the objective to carry out the classification of the solid residue in question, to analyze and to seek explanations for the values obtained, in order to characterize the residual fiber and to serve as an input for the process of decision making on the applicability of the residue in the soil. 


\section{Acknowledgements}

The authors of this paper would like to thank the support for this project provided by Universidade do Estado de Santa Catarina (UDESC), Universidade do Oeste de Santa Catarina (UNOESC) and the Laboratory of Water and Waste Treatment of CAV / UDESC.

\section{References}

ALMEIDA, H.C. et al. Influência da adição de um resíduo alcalino da Indústria de papel e celulose na lixiviação de cátions em um solo ácido. Revista Brasileira de Ciência do Solo. 2008; v32, n4, p.1775-1784.

ALMEIDA, H.C. et al. Composição química de um resíduo alcalino da indústria de papel e celulose (Dregs). Química Nova. 2007; v30, n7, p.1669-1672.

Associação brasileira de normas técnicas. NBR 10007: Amostragem de resíduos sólidos. Rio de Janeiro (Brazil): ABNT, 2004.

Associação brasileira de normas técnicas. NBR 10004: Resíduos sólidos - classificação. Rio de Janeiro (Brazil): ABNT, 2004.

Associação brasileira de normas técnicas. NBR 10005: Procedimento para obtenção de extrato lixiviado de resíduos sólidos. Rio de Janeiro (Brazil): ABNT, 2004.

Associação brasileira de normas técnicas. NBR 10006: Procedimento para obtenção de extrato solubilizado de resíduos sólidos. Rio de Janeiro (Brazil): ABNT, 2004.

BELLOTE, A.F.J. et al. Resíduos da indústria de celulose em plantios florestais. Colombo. 1998: 1-8.

FAVARO, J.S.C. Estudos da polpação kraft, branqueamento de refino de Eucalyptus grandis x Eucalyptus urophylla. [thesis]. Guaratinguetá: Curso de Engenharia Mecânica, Faculdade de Engenharia de Guaratinguetá/Universidade Estadual Paulista; 2015. $180 \mathrm{f}$.

FERREIRA, R.P.; MOREIRA, A; RASSINI, JB. Toxidez de alumínio em culturas anuais. Embrapa Pecuária Sudeste-Documentos (INFOTECA-E), 2006. 
FOELKEL, C. Os eucaliptos e os elementos não processuais na fabricação de celulose kraft. Eucalyptus Online Book \& Newsletter [Internet]. 2011. Available from: http://www. eucalyptus. com. br/eucaliptos/PT24_ElementosNproces. pdf

GOMIDE, J.L. et al. Tecnologia e Química da Produção de Celulose. Viçosa: Laboratório de Celulose e Papel, Universidade Federal de Viçosa; 2006: 235 p

KUPERMAN, R.G. et al. Toxicity benchmarks for antimony, barium, and beryllium determined using reproduction endpoints for Folsomia candida, Eisenia fetida, and Enchytraeus crypticus. Environmental toxicology and chemistry. 2006; v35, n3, p.754762.

MISHAL, B.T. Kraft pulping and atmospheric gaseous emissions. IPTTA Souvenir. 1975: 95-103.

OSSES, M. Las emisiones de olores de una planta de celulosa kraft. Celulosa y Papel. 1991: 6-16.

PERALTA-ZAMORA, P. et al. Remediação de efluentes derivados da indústria de papel e celulose. Tratamento biológico e fotocatalítico. Química Nova. 1997; 20 (2): 186190.

ROSOLEM, C.A. et al. Manganês no solo, sua avaliação e toxidez de manganês em soja. Pesquisa Agropecuária Brasileira. 1992; v27, n2, p. 277-285.

SANTANA, C.M. et al. Methodologies for the Extraction of Phenolic Compounds from Environmental Samples: New Approaches. Molecules. 2009; 14: 298-320.

SIQUEIRA, J.L.D; SILVA FILHO, LL.; SECCOMBE, R. Branqueamento de polpa kraft de eucalipto-o papel do peróxido de hidrogênio. Peróxidos do Brasil Ltda-São PauloSP, 2012.

TRIGUEIRO R.M. Efeito de "dregs e grits" nos atributos de um neossolo quartzarênico e na produção volumétrica de eucalipto [thesis]. Botucatu: Universidade Estadual Paulista; 2006. 73 p.

USEPA, Environmental Protection Agency. SW-846: Test Methods for Evaluating Solid Waste, Physical/Chemical Methods. Washington (USA): USEPA, 2015. 